\title{
W. G. Sebald as a Critic of Austrian Literature
}

\author{
RITCHIE ROBERTSON
}

The Queen's College, Oxford

Rejecting the conservative study of German literature that he encountered as a student, Sebald found inspiration in Walter Benjamin and the Frankfurt School. He re-reads Austrian literature as an expression not of conservative attachment to a home but of displacement from any home. He also explores the instabilities of the bourgeois age as revealed in fiction by Sealsfield, Stifter, Schnitzler and Hofmannsthal, and places their narratives within a wider history of colonial exploitation and ecological destruction. He then argues that the dislocation of language by schizophrenics like the poet Ernst Herbeck discloses a primitive substratum prior to the estrangement from Nature and subjection to administration of modernity. Reflections, especially Kafka's, on the death of the individual, humanity and ultimately the universe itself, lead Sebald to empathize with the messianic images found in Benjamin and other Austrian writers.

Keywords: Walter Benjamin, Frankfurt School, Sealsfield, Schnitzler, Stifter, Hofmannsthal, dislocation of language, colonialism, ecological destruction, schizophrenia, Ernst Herbeck, Kafka, messianism.

(8381 words)

\section{Criticism as opposition}

Why did Sebald choose to write so extensively about Austrian literature? A major reason must be that it is not German. Sebald's critical work largely avoids the familiar literary canon extending from Goethe to Thomas Mann. Austrian literature offers an alternative canon. Sebald's interest in Austria testifies to an interest in the marginal and the marginalized (Schütte 2002) that also shows through in his attention to Swiss writers such as Gottfried Keller and Robert Walser, and to Johann Peter Hebel, who does not fit into conventional literary histories. While some of the authors Sebald discusses are well known (Adalbert Stifter, Hugo von Hofmannsthal, Franz Kafka, Hermann Broch), his approach to them is individual and iconoclastic. His iconoclasm, however, is directed primarily against the limitations of official Germanistik.

Sebald's writings on specifically German authors tend to be angry and polemical. His undergraduate studies at Freiburg in 1963-65 left him lastingly frustrated with the refusal of mainstream Germanistik before 1968 to explore the relation between German literature and the atrocities of the mid twentieth century. Often Germanistik took refuge in a 'werkimmanente Interpretation' that excluded history, sometimes in vapid existentialist jargon like that which Sebald scornfully quotes from Fritz Martini ( $B U: 62$ ). Sebald undertook to compensate for this neglect by using his Fribourg Lizentiatsarbeit (1966) and his Manchester M.A. dissertation (1968) to expose how Carl Sternheim's work was deformed by the ideological currents of the Wilhelmine epoch; by arguing in his UEA doctoral thesis (1974) that 
the case of Alfred Döblin illustrated the self-serving unreliability of the typical bourgeois writer; and later, in his attack on Alfred Andersch (Sebald, 1993), how a well-regarded postwar author could evade the task of confronting the past (Vergangenheitsbewältigung).

In writing about Austrian authors, Sebald does not abandon his polemic against official Germanistik. He was keenly interested in the work of Austrian academics who uncovered the collusion between right-wing authors and reactionary politics under the Corporate State and the Third Reich (Sebald, 1981)). As we shall see, he treats especially Charles Sealsfield and Hermann Broch as further examples of the politically untrustworthy liberal. He also reads past literature with hindsight, looking for anticipations of the Holocaust. Even so, Vergangenheitsbewältigung is only a minor theme in his Austrian essays.

Having published numerous essays on Austrian literature, Sebald collected the majority, sometimes with minor changes, in two volumes, Die Beschreibung des Unglücks (1985) and Unheimliche Heimat (1991). The titles place the emphasis respectively on the accurate recording of melancholy, and on the feeling of displacement from a home which has ceased to feel homely. Most of the essays deal with writers whom Sebald finds sympathetic. Although Sealsfield and Broch are subjects for polemical analysis, and although Sebald always maintains a critical distance, Hofmannsthal, Schnitzler, Elias Canetti, Thomas Bernhard, Joseph Roth, and others are clearly authors he finds congenial.

Sebald's opposition to academic Germanistik helps to energize his essays. But it also has some negative consequences. Avoiding academic jargon, he too often falls into a precious style peppered with ostentatious Gallicisms (a point made by otherwise sympathetic Austrian reviewers (Loquai (1997), 54, 57)). He sometimes treats scholarly questions too lightly. Thus in his essay on messianism in Kafka's Castle he quotes from Gustav Janouch's Conversations with Kafka, whose authenticity was doubtful even in 1976, when the essay was first published in English, and by 1985, when a German version appeared, had been demolished (Goldstücker, 1980). Sebald then has it both ways by dismissively attributing doubts only to 'sceptical administrators of literature' (UH: 101) and by asserting that it doesn't matter whether or not Kafka made the statement ascribed to him by Janouch (in which case, why quote it?).

By defying the conventions of Germanistik, Sebald's essays belong to a critical genre that is perhaps more familiar in anglophone than in German writing. Disappointed in his teachers - and, as his book reviews show, in the tendency of Germanistik generally, in Britain as well as Germany, to avoid urgent questions (Schütte 2008) - Sebald found an alternative source of ideas in the writings of Walter Benjamin and the Frankfurt School. Recalling his studies at Freiburg, he writes: 'I have often wondered how dismal and dishonest our understanding of literature would have remained, if the writings of Benjamin and the Frankfurt School, which after all was a Jewish school researching bourgeois social and intellectual history, had not provided us with new perspectives' (Sebald 1998, 12). In addition, Sebald relies heavily on psychoanalysis and (in the broadest sense) on anthropology. His use of psychoanalysis, though often valuable, can be disturbingly facile, as when he asserts that psychoanalysis regards journeys and travelling as symbols of death ( $B U: 78)$, that a challenge to a duel is a threat of castration $(B U: 49)$, and that gambling symbolizes bisexuality ( $B U: 67)$. He occasionally resorts to the 'heads I win, tails you lose' type of argument often favoured by psychoanalytic commentators. Thus the psychic wounds inflicted on Stifter by his early poverty are supposed to be apparent, not from 
obsessive references to money, but from the absence of such references ( $B U: 20)$. Anthropology features obtrusively when Sebald tries to support an interpretation by appealing to alleged anthropological constants, such as the association of power and excrement asserted by Christian Enzensberger ( $U H:$ 89-90, BU: 104) or the claim by Gaston Bachelard that digestion is the strongest form of realism (BU: 26). These quotations may be rhetorical appeals to an authority higher than that of Germanistik, but they weaken Sebald's essays by sounding merely eccentric and by distracting attention from the intuitive brilliance which is the real source of his critical authority.

Sebald did not gain an intellectual system from the Frankfurt School, for he was well aware of the power of intellectual systems to stifle their object, and sympathized with Canetti's view of systematization as a form of paranoia ( $B U: 95)$. Rather, the Frankfurt School gave him a loose scheme of historical development which enabled him to place his authors in history, and on occasion to criticize their political stances, without violating the integrity of their work. In this historical scheme, Sebald is especially interested in the bourgeois age (roughly equivalent to the long nineteenth century) in which the middle classes, succeeding the ancien régime which was fatally weakened by the French Revolution, instituted their own regime of work, religion, patriarchy and sexual repression. The bourgeoisie upheld the ideology of progress, often understanding it in Hegelian terms as 'the redemptive doctrine of the gradual unfolding of the World Spirit' $(B U: 18)$. In the early twentieth century the bourgeois age was in turn overthrown by war, inflation, feminism, mass movements of left and right, and the undermining of its moral certainties through science and psychoanalysis. Some of Sebald's most astute essays concern writers such as Schnitzler and Hofmannsthal who reveal, despite themselves, the insecurity and instability of the bourgeois regime.

In addition, and more importantly, Sebald derived from Adorno, Horkheimer and Benjamin an imaginative vision of history. In this deeply pessimistic vision, inspired especially by Dialektik der Aufklärung (1947), 'progress' is an illusion. The advance of reason, science, enlightenment, and liberty is also an increase in unreason, superstition, and oppression (Hutchinson, 2009). 'Progress' has led us to an administered world in which rational efficiency is applied to inhuman ends, including warfare, the Holocaust, and the ongoing destruction of nature by an uncontrollable turbo-capitalism. Any attempt at compromise with the administrative machine in which we are trapped is shameful; any attempt to ameliorate its effects is futile. If one rejects its blandishments, one condemns oneself to a melancholy which is, as Sebald insists, already a form of resistance against the relentlessly upbeat ideology of progress. Another form of resistance is art - above all, the 'difficult' art which cannot readily be assimilated and is often, like Peter Handke's later work, vilified and marginalized by the literary market ( $U H: 162)$. Such art may be utopian or apocalyptic. It may evoke an ideal form of life antithetical to the limited possibilities available within the administrative machine; or it may summon up images which threaten even the machine itself with destruction and retribution.

\section{Homelessness}

Sebald's critical stature emerges most impressively from essays devoted to authors he likes, and who are linked by some features - perhaps one should follow Wittgenstein in talking about 'family resemblances' - which help to explain his choices. They express and explore unhappiness in pellucid language of great symbolic density and suggestiveness - Stifter, Kafka, the Hofmannsthal of Andreas (1932), Joseph Roth 
especially in late, parable-like stories such as Das falsche Gewicht (1937) - in which one recognizes a common tone of voice and a commitment to linguistic precision. The latter in turn is connected with the acute consciousness of language that finds expression in Austrian writing from the beginning of the twentieth century onwards, notably in such landmarks as Fritz Mauthner's Beiträge zur Kritik der Sprache (19012) and Hofmannsthal's Chandos Letter (1902).

In the preface to $B U$ Sebald gives a brief catalogue of Austrian writers afflicted by various forms of depression, beginning with Ferdinand Raimund and the terror of death that underlies his comedies, and ending with the deaths in exile of Joseph Roth and Ödön von Horváth. There is no need to add Thomas Bernhard, for he is a pervasive presence in Sebald's writing. German literature, of course, is only too full of troubled, depressive writers who ended in madness and/or suicide, such as Lenz, Kleist, and Hölderlin. But with Sebald's Austrians, melancholy is linked to emotional authenticity and to conservatism. Sebald often acknowledges an emotional authenticity that can emerge in spite of the author's conscious intentions. Thus Stifter no doubt wanted to deliver the positive message that his hagiographers of an earlier generation so often claimed to be the exclusive content of his works. Between the lines, however, he keeps giving expression to suppressed fears and fantasies, and his involuntary honesty leads to such unforgettable passages as the one Sebald quotes from Die Mappe meines Urgroßvaters in which the Colonel, recounting the death of his wife in a horrific accident, at last utters the true voice of feeling ( $B \mathrm{U}: 36)$.

Sebald's Austrians show their conservatism in the scepticism about 'progress' which is of course a hallmark of Austrian writing. Its most famous expression comes from Johann Nestroy, the great comic dramatist who is strangely absent from Sebald's writings. In Der Schützling (The Protégé, 1847), the unfortunate Gottlieb Herb delivers a monologue on progress:

And yet we live in an age of progress. Progress is like a newly discovered country: a flourishing colonial system along the coast, while the interior is still wilderness, steppe, prairie. Altogether, progress looks much greater than it really is (Nestroy (2000) 91).

By contrast, the physical destruction of the past by rebuilding, and the consignment of past experience to oblivion, seemed to Sebald characteristic of postwar Germany, as he repeatedly told interviewers. In Austrian writers, therefore, he found a melancholy attachment to the past which matched his own rejection of capitalist modernity. Hence his favoured theme of 'Heimat' ('home' or 'homeland') on which Sebald chooses to focus is ambivalent, expressing both a regressive attachment to the past and a resistance to the obliteration of the past by the forces of progress.

The word 'Heimat' has a particular resonance in Austrian literature. The 'Heimatroman' (regional novel of rural life), a genre that developed in the late nineteenth century, celebrates the sturdy, timeless virtues of the farmers, bound to the soil and to the cycle of the seasons and deplores the malign influence of cities, which attract population away from the land; of machinery; and of the money economy which replaces quasi-feudal personal relations with impersonal money-based ones. In the Corporate State set up after the defeat of Socialism in the Austrian Civil War of February 1934, 'Heimatdichter' (regional writers) such as Karl Heinrich Waggerl, author of Schweres Blut (1932), were feted for their conservatism; Waggerl was typical in adopting Nazism after the Anschluss in 1938. Given this tainted history, many postwar Austrian novels - Thomas Bernhard's Frost (1963), Peter Handke's 
Wunschloses Unglück (1974), Robert Schneider's Schlafes Bruder (1992) - have concentrated on exposing the misery of rural life (see Long (2006), 226-30). Sebald briefly surveys this history in the preface to $U H$, showing how much Austrian literature has been inspired, not by rootedness in a 'Heimat', but by exile and by mourning for a lost home, and stressing the physical destruction of the landscape which ought to be the predestined setting for human life. He deals harshly with the political and commercial exploitation of 'Heimat' in twentieth-century Austria, shown for example in the promotion of regional costumes (Trachten), which accompanied the ecological devastation of the Alpine 'Heimat' (UH: 167).

Sebald complicates the concept of 'Heimat' by refusing to regard it as the prerogative of German-speaking Austrians. He discusses how Handke's protagonist Filip Kobal goes in search of his Slovenian 'Heimat' $(U H$ : 166), while an impressively well-informed essay deals with nineteenth-century 'ghetto fiction' in which Jewish writers express qualified nostalgia for the restrictive but homelike Jewish regions of Eastern Europe. Sebald here discusses such uncanonical writers as Leopold Kompert, Karl Emil Franzos, and Leopold von Sacher-Masoch (not a Jew, but often a philosemite), showing how their ambivalence is fully developed by Joseph Roth in his literary evocation of Galicia, the easternmost province of the Austrian Empire from whose Jewish population Roth himself derived. The Viennese Peter Altenberg is treated as an urban flâneur, comparable to Baudelaire (UH: 81); he advertised his attachment to his lost 'Heimat', the town of Altenberg on the Danube, by adopting its name as a pseudonym. Homeless in Vienna, a denizen of coffeehouses, he offered more established writers of Jewish origin a warning of their insecure position. Sebald, making free use of hindsight, says that Altenberg's writing, as Adorno said of Mahler, is a prelude to emigration (UH: 78).

Far more drastic was the case of Jean Améry. Brought up as Hans Mayer in the Alpine holiday resort of Bad Ischl, where his mother kept an inn (his father died in the Great War), he had no interest in his Jewish ancestry, yet found himself expelled from Austria in 1939 and eventually swept up in the Holocaust, where he survived incarceration in Auschwitz. In his new identity as Jean Améry he disclaimed any identification with a 'Heimat', yet maintained - especially in his essay 'Wieviel Heimat braucht der Mensch?' ('How much homeland does a person need?') - that to have an identity one needs a 'Heimat', familiar surroundings, one's native language, and contact with early memories: "One needs to be able to say "we" in order to say confidently "I"' (Améry (2002), 90). Améry suffered, as Sebald notes, from feelings of homesickness which in 1978 drove him to suicide. Améry was a crucially important figure for Sebald, whose writings on him extend far beyond $U H$ (see Heidelberger-Leonard (2005)); but the essay serves to demonstrate the hollowness of the conventional conception of 'Heimat'. More generally, Sebald attacks this conception by showing that Austrian literature does not evoke people firmly established in a home region, but is rather a literature of displacement. Its writers and its literary figures are alienated from their childhood, their places of origin, and their native cultures.

\section{The hollowness of liberalism}

An extreme example of such alienation was Karl Postl (1793-1864), better known as Charles Sealsfield, whose novels of American life were admired in the 1840s but have since then, as Sebald rightly observes, vanished from the canon. As a young man Postl became a monk, but in 1823 he left Austria for America. He revisited Europe 
briefly in 1826 and published in Stuttgart a well-informed factual account of the United States, Die Vereinigten Staaten von Amerika, and in London a polemical account of Austria under Metternich, Austria as it is. Returning to America in 1827, he wrote a series of novels set there, beginning with The Indian Chief or Tokeah and the White Rose (published first in English, 1828) and including what in the nineteenth century was his best-known work, Das Kajütenbuch (1843). From 1830 he lived mostly in Europe, finally settling in Switzerland, where nobody knew that he had once been Karl Postl. Sebald treats Sealsfield as an example of bourgeois bad faith, in a way that recalls his study of Döblin.

Sealsfield is sometimes thought to have been a devotee of liberty, even an incipient revolutionary, who left Austria because he could not endure the despotic rule of Metternich. Drawing on the factual evidence provided by Eduard Castle's biography, and extending it by plausible conjectures, Sebald presents a very different picture. Postl in fact made repeated attempts to obtain employment with the Metternich regime, first by appealing unsuccessfully to the well-known reactionary Graf Saurau, and then, on his return to Europe in 1826, by writing directly to Metternich and offering his services as a spy. Sebald concludes that Postl left Austria simply because he had failed to gain political employment and because, having broken the monastic rules by making an unauthorized visit to Vienna to see Graf Saurau, he was officially a criminal. Even Austria as it is is not primarily an attack on Metternich's despotism but a money-making venture which denounces Austria in order to flatter complacent English readers. Thereafter, abandoning his original identity, the new American Charles Sealsfield concentrated on writing profitable novels and investing the proceeds in railway shares and the like.

This portrait of Postl/Sealsfield contains some ambiguity. In denouncing Metternich in print just after seeking employment from him, Postl would seem to have been merely unprincipled, ambitious, and duplicitous. But Sebald wants him also to illustrate the shallowness of self-styled progressive liberalism, its willingness to discard its professed ideals and to reach shabby compromises with the ruling powers. Hence Postl's ideals must at one time have been sincerely held:

The way this seemingly progressive writer prepared to sell his political soul anticipates the trahison des clercs that is widespread in bourgeoius literature yet has barely been explored; it was motivated not least by fear of destitution and social degradation (UH: 22).

Sealsfield compounded this treachery by engaging in Bonapartist intrigues, and by disapproving of the 1848 revolution in Vienna, which he wanted to see concluded by a massacre of a few hundred hotheads at the hands of a ruthless minister or general. Thus he serves - depending on how the above-mentioned ambiguity is resolved - to illustrate either the hollowness or the unreliability of professed liberal principles. He lived 'early in the era of high capitalism' and embodied its contradictions (UH: 18). He even fantasized about ending up in the White House (UH: 22). ${ }^{1}$ His attitude to

1 Sebald gives an incorrect reference. The statement: 'seine Rolle, sagte er [Sealsfield], liege überhaupt nicht in der Literatur, sondern im weißen Hause', is in Castle 1943: 347, whereas Sebald gives it as p. 436. The anecdote is also very uncertain: it concerns a conversation in 1838 or thereabouts, and is reported at second hand by the Swiss pastor Friedrich Hemmann, who knew Sealsfield late in life, in a memoir published in 1879 . 
power was ambivalent: 'not even in the period before 1848 was a liberal ideology incompatible with a reactionary political praxis' $(U H: 23)$.

\section{History as decline}

If Sealsfield represents the unacceptable aspects of the bourgeois age, Stifter, of whom Sebald provides two iconoclastic studies, is a far more complex case. After his rediscovery early in the twentieth century, Stifter was elevated into a saintly figure and exploited to bolster a literary and political conservatism. Sebald's account of the hagiographical tendency in Stifter criticism is broadly correct, though he overlooks such a powerful contrary voice as Erik Lunding. Lunding's study (1946), published significantly not in Austria or Germany but in Denmark, persuasively presents Stifter as driven into a state of constant fear by loneliness and by awareness of his own violent, demonic impulses, and hence determined to suppress passion at all costs.

Although Sebald calls for a pathographical study of Stifter which should, among other things, account for his compulsive eating (bluntly mentioned at $B U: 21$ and 170-1), he regards Stifter primarily as embodying the uncertainties and fears of someone who exists on the fringes of the bourgeoisie. The dread of being reduced to poverty and sinking into a lower class which haunted the bourgeoisie was particularly acute for Stifter since in his early years he made his living as a private tutor, and he was not freed from pressing money worries until his appointment as an inspector of schools at the age of forty-five. Sebald relates the sexual imagination in Stifter's fiction to the lasting effects of his social position. Stifter shows an obsession with young virginal girls, often described as children, and desexualizes them further by dressing them in dowdy old-fashioned clothes, like the grey dresses worn by Natalie in Der Nachsommer. Sebald argues that Stifter, having spent many years close to attractive and unattainable young women from a higher social class, may well have restrained his own desire by displacing it onto their clothes in a form of fetishism; though the further implication that Stifter disguised his own fetishism by making his heroines sexless and dowdy makes this argument seem rather strained. At all events, Stifter's frustration, along with his own disappointing experience of marriage, accounts for the quietly searing account of the growing estrangement between a married couple in the story Prokopus. Even Stifter's compulsive eating may be explained partly by his need to affirm his membership of bourgeois society through conspicuous consumption (BU: 172).

There is one critical approach to Stifter, popular in the 1960s, that Sebald avoids. That involves arguing that the absence of politics from his fiction amounts to a political quietism which in turn implies de facto support, first for the authoritarian regime of Metternich, and then for the restoration of conservative rule after 1848 (e.g. Glaser (1965)). Against such arguments, Sebald points out that Der Nachsommer (1857) is not an affirmation of contemporary society, but a timeless utopia located outside history. However, he also suggests that history re-enters Der Nachsommer by the back door through its famous descriptions of nature. Beautiful as these are, they express a fascination with nature which developed only when nature was being subjected to commercial exploitation: 'The description of nature, in literature and elsewhere, developed only when the world was opened up to commerce' (BU: 25). The description of nature was the first step towards its expropriation; Sebald suggests that Stifter felt guilty even about looking at nature, since looking is a means of taking 
possession. Most of Der Nachsommer takes place not in untamed nature but on a carefully ordered estate in which nothing can escape control. A bee-eating bird, the redstart, is exterminated ('ausgemerzt', BU: 22; Sebald no doubt deliberately uses a word suggestive of twentieth-century atrocities), and the countryside around the estate seems empty of human and animal inhabitants (here Sebald is closely following Glaser (1965), pp. 12-14). Thus Stifter's utopia, while not an affirmation of political reaction, turns out to be something even more consequential, a celebration of a bourgeois order that is ultimately deadly.

The decline of bourgeois society is addressed in two of Sebald's most perceptive essays, those dealing with Schnitzler's Traumnovelle and Hofmannsthal's unfinished novel Andreas. The former essay is developed from an incisive shorter piece that showed how the prominent social reality of prostitution in late bourgeois society was mythologized in its literature (Sebald (1983)). In Schnitzler's story, Sebald finds the same sexual economy exposed with exceptional honesty. Although the married couple at the centre of the story, Albertine and Fridolin, enjoy considerable erotic harmony, they inevitably also suffer from unsatisfied emotional desires. Albertine hankers after a more impressive type of man than her bourgeois husband, a military type whose uniform recalls the pre-bourgeois era. Fridolin by contrast can realize his desires in action, having access to the vast semi-invisible reservoir of prostitution. The woman's fantasies run parallel to the man's promiscuity: both support the bourgeois social system centred on the nuclear family. There are, however, grimmer possibilities. Fridolin, a doctor, visits a household where the father has just died. His daughter Marianne, who has spent years caring for the domestic tyrant, exemplifies the hysteria which male-dominated society imposes on women both by disempowering them and by projecting onto them the male fear of women. On her wall Marianne has a picture of her brother in military uniform, which Sebald interprets as a fetish-object expressing both the feminine fantasy-ideal already mentioned and an unacknowledged incestuous desire. Fridolin also refrains from picking up a prostitute and soon afterwards learns that the woman who offered herself is infected with syphilis. Digressing into Schnitzler's autobiographical writings, Sebald comments on how the risk of an incurable infection was felt both as a challenge, a kind of dare, and also as a fate that struck at random. Sebald thus astutely uses Schnitzler's work to disclose past structures of erotic feeling.

Unlike many commentators on Traumnovelle, Sebald is relatively uninterested in the central episode, in which Fridolin is introduced into a suburban mansion where members of a secret society, dressed as knights and nuns, gather for erotic orgies. $\mathrm{He}$ rightly points out that this episode feels abstract in contrast to the analytic precision and vividness with which Schnitzler explores the erotic undercurrents of everyday life (BU: 48). However, the episode has an important narrative consequence. When Fridolin's intrusion is discovered, he is threatened with death, but a woman offers her life for his. Later she commits suicide, and Fridolin views her corpse. Sebald ends his essay by quoting this passage at length in order to illustrate the necrophilia which is the inadmissible shadow-side of the bourgeois ideal of love. He does not discuss the actual ending of Traumnovelle, in which Albertine and Fridolin confess their fantasies and adventures to each other and thus re-establish their domestic life. Sebald is more interested in deconstruction than in reconstruction.

There is plenty to deconstruct in Hofmannsthal's Andreas, the subject of one of Sebald's most brilliant and persuasive analyses. Bearing in mind Hofmannsthal's often-stated commitment to marriage and social responsibility, this fragmentary novel has been read as an attempt at a Bildungsroman which should show the hero attaining 
integration into society. Leaving aside the fact that very few Bildungsromane do show this, Sebald demonstrates that Hofmannsthal's novel actually explores the erotic, incestuous, perverse and sadistic desires which are rendered taboo by the bourgeois sexual economy. Young Andreas is afraid of sex, imagining it as 'murder in the dark' (quoted $B U: 66$ ). He can be at ease with a young woman only by imagining her as his sister and thereby evoking decadent fantasies of incest. He encounters threatening homosexual figures. One is the brutal and insubordinate servant Gotthelff, whom Sebald associates with Arcangeli, who murdered the art historian Winckelmann in an inn at Trieste in 1768 ( $B U: 67) .^{2}$ Another, more persuasively identified, is the mysterious, frightening and charismatic Knight of Malta whom Sebald associates with the traumatic encounter between the seventeen-year-old Hofmannsthal and the aggressive homosexual Stefan George (see Rieckmann (1997)). Andreas himself, the text implies, has as a boy suffered sexual harassment from his teacher of religion, and his sensibility includes a large portion of decadent sadism. Sebald repeatedly links him with Baudelaire, the deliberately dandified and perverse opponent of bourgeois society, implying that Andreas embodies the inadmissible shadow-side of Hofmannsthal's conscious commitments.

In retrospect, according to Sebald, bourgeois society can be seen to have strengthened its false security not only by repressing inadmissible desires but also by relentlessly marginalizing outsiders. Their exclusion anticipated the massive destruction of undesirable persons by the Third Reich.

All these developments are embedded in a wider history, which Sebald illustrates by examining Sealsfield's American fiction (mainly Das Kajütenbuch). Sealsfield serves to typify the European expansion across the globe which included the enslavement and extinction of indigenous populations. According to his biographer, Sealsfield was notorious for defending American slavery on the grounds that economic interest made the Americans treat their slaves better than they did their hired white labourers. Correspondingly, Das Kajütenbuch contains an idyllic description of a village inhabited by slaves followed by an account of the affection they feel for their masters. With the native Americans Sealsfield is more ambivalent. In his first novel he makes the chief Tokeah lament affectingly the destruction of his people's lives and habitat by the American settlers. Sebald interprets this passage as a disguised expression by Sealsfield of his own discomfort as an exile. Yet Sealsfield is said also to acquiesce in the widespread nineteenth-century assumption that the native Americans, like other indigenous peoples, were naturally inferior to the white race and ineluctably destined to be swept away by it - though Sebald's evidence that Sealsfield held this view is confined to one passage, which Sebald does not actually quote, from The Indian Chief, supported by quotations from Darwin and from Sealsfield's biographers. Sebald may be right in crediting Sealsfield with such assumptions, but his treatment of the evidence is somewhat prejudicial. His animus is directed partly against Sealsfield's conservative biographer Eduard Castle (18751959), a professor at Vienna University, who explicitly agreed with Sealsfield that the 1848 revolution should be suppressed by a massacre, and who described the disappearance of the native American races as a natural necessity (Castle (1952), 517, 249) - at a time, as Sebald notes, when the disappearance of the Jews of Europe was similarly being enforced ( $U H: 31)$. Castle thus serves briefly but drastically to illustrate the complicity of traditional Germanistik with twentieth-century tyranny.

\footnotetext{
2 Although Winckelmann was homosexual, the motive for his murder is now thought to have been merely robbery: see Gossman (1992).
} 
The European extermination of foreign races is an aspect of the larger history of destruction which forms Sebald's master narrative of history. In celebrating the conquest of the American frontier, Sealsfield depicts the antagonism between humanity and nature which, according to Sebald, was sharpened by the dynamics of capitalism, and which finds expression in a passage from Das Kajütenbuch that Sebald quotes at length. It describes how in Texas wild horses are broken by having a heavy bit inserted in their mouths to lacerate their sensitive flesh when they show any disobedience, and how, thus equipped, they are ridden to exhaustion by horsemen with six-inch-long spurs. This is indeed an arresting and horrifying passage, but in using it to illustrate the violent subjection of nature to the human will, Sebald ignores the disapproval that Sealsfield's narrator registers by evoking the pain suffered inflicted on the horses, by repeatedly using the word 'furchtbar' (frightful), by ascribing the practice to Mexicans, not to Americans, and by observing that this method of taming the horse renders it vicious (UH: 35; Sealsfield (1982), 27-8).

Sebald's master narrative includes a turning-point where humanity and nature are decisively estranged. He locates it in the early nineteenth century, telling us: 'Sealsfield's descriptions of nature emerged at the decisive turning-point where nature finally ceased to be humanity's natural home ('Heimat')' (UH: 37). To support this claim, he cites the description of Galveston Bay, where the flat and featureless land can barely be distinguished from the water, early in Das Kajütenbuch, and adds that this desolation looks like the world at the beginning of creation, when land and water were not yet separate; hence Sealsfield's description implies that man needs to continue the work by shaping, subjugating, and exploiting the natural world. Indeed, according to Sebald, literary descriptions of nature confirm, by their very existence, humanity's alienation from nature and thus its availability for humanity to exploit. Such assertions, however, seem to betray a wishful eco-romanticism, for historical studies suggest that pre-industrial societies were lacking, not in the will to exploit nature, but merely in the means of doing so effectively (Thomas, 1983).

Stifter too shows nature suffering at the hands of humanity. Here, however, Sebald becomes somewhat obscure. He ascribes to Stifter an insight into the relation between nature and economics that is comparable to the insights of Marx (BU: 26). But he supports this extraordinary claim only by briefly discussing a passage from Die Mappe meines Urgroßvaters in which the main characters are planting a wood for the benefit of future generations, and suggesting that Stifter reveals an awareness that the balance between aesthetic and economic standards - natural beauty versus commercial profit - is unstable. This ecological perspective is undoubtedly present in Stifter (for example, in the references to deforestation in 'Granit'), but the consequences Sebald draws from it seem wilful.

\section{Schizophrenia as protest}

Alongside this political criticism, and linked with it in a manner that only gradually becomes apparent, Sebald shows a particular interest in the relation between literature and schizophrenia. He gives a close analysis of the presentation of successive stages of schizophrenia in Handke's Die Angst des Tormanns beim Elfmeter (1970), where Handke, with praiseworthy sobriety and precision, offers 'a concrete phenomenology of behaviour governed by fear' $(B U: 120)$. Sebald begins by reflecting that psychiatric case histories have difficulty in identifying the point where normal behaviour slips over into pathological behaviour, and suggests that literature, or at least literature written with Handke's combination of matter-of-factness and empathy, might help the 
psychiatrists. Handke does not explain, but he does show, how Bloch gets from a state of suspicion into one of panic, how he temporarily conquers his panic by strangling the woman he is sleeping with, and how his schizophrenia develops through auditory hallucinations, disturbed vision, estrangement from his native language, and a sense that his own body (like Gregor Samsa's) has somehow become loathsome. Sebald further reads schizophrenia as the loss of the support of the civilization that habitually surrounds one and as returning to an archaic state of savagery and constant fear, like a hunted animal.

Schizophrenia and regression are also associated in Sebald's essay on Ernst Herbeck, a schizophrenic patient who has published poems under the pseudonym Alexander [Herbrich]. The only difference, in Sebald's opinion, between these poems and officially recognized literature, is that the stage of dissociation which is part of the creative process is here not overcome but is inscribed in the poems themselves as eccentric verbal collocations, odd punctuation, and the like. Analysing the poem that begins 'Die Rote Farbe', Sebald finds in it some coherence and much poetic suggestiveness. He is impressed also by some poems where Herbeck alludes to Hitler and the Second World War. By introducing both himself and Hitler into a cryptic poem, Herbeck suggests the symbiotic relation between power and powerlessness which, as Sebald notes, is also a central theme in Kafka (BU: 144).

Sebald pays much attention to a remarkable and neglected Austrian novelist, Gerhard Roth. About Roth's bestseller Winterreise (1979) he is unenthusiastic. Uninterested in its account of how an Austrian schoolteacher seeks vainly for meaning in life, Sebald concentrates on the novel's pornographic scenes and easily demonstrates how badly written they are. Beyond this, he complains that Roth is still committed to a conventional realism, whereas the pornographic imagination strives to construct a self-contained pornotopia. In the immense novel Landläufiger Tod (1984), however, Roth's imagination takes off. This astonishing book deserves to stand alongside Bernhard's Auslöschung (1986) as an example of Austrian

'Vergangenheitsbewältigung'. Sebald, however, is mainly interested in how it explores the mind of Franz Lindner, a schizophrenic patient who forms its narrative centre. Roth is here drawing on a long-standing fascination with schizophrenia that was nourished by his medical training, his studies of schizophrenic art, and, above all, by his acquaintance with Ernst Herbeck and other gifted schizophrenics (see Schütte (1997)). Like Sebald, Roth sympathizes with Foucault's view that 'madness' is a category invented to marginalize the socially unacceptable, and doubts that any hard and fast line can be drawn between the creative productions of the 'mad' and the 'sane'. Hence his novel includes not only realistic narratives but also surreal fantasies, fairy-tales, and cryptic though suggestive aphorisms, all attributed to Lindner. Thus, in Sebald's view, Roth goes beyond the essentially tautological realist reproduction of reality and conveys another reality, unfamiliar to most people, repressed by civilization, and comparable to the pensée sauvage analysed by Lévi-Strauss.

For Sebald, Herbeck's poetry and Roth's writing illustrate a specifically Austrian interest in the origins and implications of language use that is famously explored in Handke's play Kaspar (1968). Discussing Hofmannsthal's neglected masterpiece Der Turm, he compares Handke's figure with Hofmannsthal's aphasic Sigismund (Sebald (1978), 296-7). What especially intrigues him about all such socially marginal modes of utterance, however, is that they reach back to a symbolic form of thinking that antedates the instrumental use of language. 'For symbolic thought, the utilitarian conception of language is either alien or absent; it does not intend a final de-scription of reality, but a continuous engagement with it' (BU: 134). 
The hyphen in 'de-scription' (Sebald wrote 'Be-schreibung') implies that utilitarian language forcibly inscribes its own purposes onto a passive, subjugated reality. Sebald also associates Herbeck's mode of composition with Lévi-Strauss's reflections on mythical thinking and the savage mind. Like the penseur sauvage for whom myths are not pictures of reality but something good to think with, Herbeck does not use language to represent reality but engages with language as an equal partner in dialogue. Thus the poetic image used by the schizophrenic reconnects us with a primitive stage when concepts - or as Sebald calls them, 'projective and discursive mythologemes' (BU: 132) - such as God, the Beyond, Freedom and Justice were not yet necessary because humankind was not yet estranged from reality and did not yet need language to bridge the gulf that would soon open up between immediate experience and conceptual thought.

These reflections on language tie in with Sebald's conception of history as a narrative of alienation. In the bureaucratized modern world, where all life is subject to discipline, regulation, and exploitation, freedom and creativity survive only in the writings of schizophrenics, who are marginalized not only by the health care system but by the prevailing rules of rational discourse. Sebald's sympathy with the outlook of schizophrenics further recalls the anti-psychiatry movement of the 1960s, associated in Britain especially with R.D. Laing, though Sebald is more indebted to Leo Navratil, a professor of psychiatric medicine at the Niederösterreichische Landeskrankenhaus für Psychiatrie und Neurologie at Gugging, near Klosterneuburg. In 1981 Navratil founded the 'Haus der Künstler' in the grounds of the Gugging clinic, where schizophrenic poets and artists such as Herbeck could live together.

It may seem as if here, too, Sebald is a romantic, harking back to the primitive past in search of an unspoiled residue buried beneath the monstrous edifice of the rational, bureaucratized world. But the case is not so clear as with Sebald's historical scheme, for in many parts of his critical work he steps outside history altogether. He insists on the close affinity between art and metaphysics (UH: 163). His thinking becomes metaphysical, utopian, and apocalyptic. His pessimism is not discontentment with this or that feature of the world, but a refusal to accept the very conditions of human existence. Among these are of course the fact that all life tends towards death, something for which the sterile, snowbound landscape of Kafka's Castle provides the perfect literary correlative. Sebald's fine essay on the omnipresence of death in Kafka's novel may occasionally be arbitrary in forcing textual evidence into its scheme, as when the apparently incongruous telephone is explained as a 'mystagogical apparatus' ( $B U: 89)$ and the Castle officials are said to be keeping a register of the dead; but it scores valuable points by associating the novel's two inns with the legend of the 'Nobiskrug', where the dead have their last drink, and the Herrenhofwirtin with the figure of 'Madame la Mort' which Kafka saw performed by the actress Rachilde in a cabaret in 1912 (Kafka, 1990: 421).

In another meditation on Kafka (Sebald, 1986), which richly deserves reprinting, Sebald notes contemporary predictions that humanity will mutate, perhaps soon, into mechanical entities or cyborgs, and relates them to Kafka's fantasies about evolution. Focusing on 'Ein Bericht für eine Akademie' ('A Report to an Academy', 1917), Sebald reads it as a devastating critique of all doctrines of progress, particularly of those that seek support from Darwin's theory of evolution. For Kafka shows that in order to enter civilization, one has to put one's animality behind one and reject any thought of escaping from one's situation. Only the docile, submissive animal can be trained. Hence Rotpeter is a miserable in-between creature, no longer 
an animal, not yet human, while the academicians who receive his report in silence may, for all we know, already be the inorganic beings of the post-human future.

Sebald frames the death of the individual, and the death of humanity within a wider picture of entropic decline. Since, as the Second Law of Thermodynamics tells us, heat loss is invariable, the universe is running inexorably down towards annihilation. This idea breaks surface several times, often perplexingly, in Sebald's essays. Thus we are implausibly told that Stifter perceived that all natural systems are subject to entropy ( $B \mathrm{U}: 26-7)$. Gerhard Roth is said to envisage history as merely part of larger, inexorable, 'continuous processes of dissolution' within nature (UH: 154). Bernhard gains Sebald's approval by refusing to imagine that nature can ever become a home for humanity; such fantasies, whether in Marx or Stifter, are dismissed as a mere threadbare compensation for the twofold destruction of nature, both through its exploitation by humans and also through the internal dissolution which will end in the heat-death of the universe (BU: 108-9).

In this situation, conventional religion offers no comfort. The decline of religious conviction in the last few centuries - illustrated for Sebald by the priest in Kafka's 'Ein Landarzt' ('A Country Doctor', 1917) who tears up his own vestments $(B U: 18)$ - means that it is no longer possible to see the world as intrinsically meaningful. By the nineteenth century, the project of giving meaning to the world was entering a state of atrophy. When Stifter tried to deny this development, he produced the notoriously static historical novel Witiko, in which he unsuccessfully attempts to convey a providential meaning in history $(B U: 18)$. In more truthful moods, he gives us descriptions, even catalogues, of material objects, not because they embody any meaning, but just because they are there.

Sebald maintains that despite his professions of Christian faith, Stifter in his stories reveals himself as an agnostic. Either the universe has no divine or metaphysical meaning, or it contains a destructive force that is indifferent to anything else ( $B U: 24$; the obvious parallel, though Sebald does not draw it, is with Schopenhauer's concept of the Will). Such a force intervenes in the story Abdias as the lightning which gives sight to Abdias's blind daughter Ditha, but later kills her.

It is the metaphysical ambitions shown by Hermann Broch that especially prompt Sebald's attack on the unfinished novel variously entitled Bergroman, Der Versucher, and Die Verzauberung (written 1934-6). Ostensibly an anti-Fascist text showing how a charismatic stranger reduces the inhabitants of a Tyrolean mountain village to a state of mass hysteria in which they perform a human sacrifice, Broch's novel has often been criticized for adapting the genre of the 'Heimatroman' whose reactionary implications suited the conservative Corporate State in which Broch was working (Duebbert, 1983). Sebald shows his originality by criticizing Broch's novel not directly for its political ambiguity but for its untenable ambition to fill the postChristian metaphysical void and for the sheer bad writing with which Broch attempts to do so. Only then, having made his case against Broch by means of literary analysis, does Sebald draw the political conclusions: he reveals the actual defeatism underlying Broch's anti-Fascist rhetoric and finds in him yet another example of trahison des clercs (UH: 125). The essay on Broch shows powerfully how a phoney ideology can be exposed by literary criticism, and delivers a justified rebuke to official Germanistik for laboriously hunting down Broch's sources while failing to confront the dubiety of the entire Bergroman project.

Given the post-Christian void, how does Sebald the critic propose to fill it? Not by offering some substitute for religious belief, and certainly not by reviving nineteenth-century grand narratives such as that of progress which have been 
decisively discredited by twentieth-century history. Instead, with Benjamin's book on Baroque tragedy particularly in mind, he pays attention to writers who speak the language of utopia and apocalypse. According to Benjamin, Baroque writers rejected the earthly world outright, treating it only as a setting where allegorical images of the last things could become visible. Similarly, Sebald finds in Joseph Roth, especially in the account of the Corpus Christi procession in Radetzkymarsch (The Radetzky March, 1932), a transcendence of earthly matters which allows an eschatological vision of the heavenly city to emerge. Roth's utopia is predicated on an absolute rejection of earthly life. His wandering Jews, who have no home and no consolation in their state of exile, need utopian images, not to alleviate their situation, but to provide an imaginary antithesis to it (UH: 110).

By contrast, the utopia in Stifter's Der Nachsommer is inauthentic and fragile: it is an imaginative attempt to transcend the conditions of earthly life by creating a static heaven; but it remains two-dimensional, because Stifter carefully avoids inquiring into the sources of the unhappiness for which his writing is a compensation. Sebald finds a different quality of writing, and a stronger authorial presence, in the rare passages where Stifter actually expresses the panic that always threatened him. One is the balloon ascent in the early story 'Der Condor' (1840), another the autobiographical account of being trapped by a snowstorm in the Bavarian Forest. Stifter scholars often, disappointingly, read such passages merely as expressions of Stifter's personal neurosis (e.g. Schiffermüller 2007). Sebald goes further by finding in them intimations of a heretical, Gnostic world-view. When Stifter's balloonists discover that clouds, close up, resemble cold wet shrouds, or when the snowstorm obliterates all features of the landscape, the world is revealed in its true, deathly character.

The conception of a hopelessly fallen, desolate world provokes a search for images of deliverance. These are not to be found in secular ideals of progress within history, but in apocalyptic and messianic manifestations such as the revolutionary conclusion of Hofmannsthal's Der Turm, which was reviewed admiringly by Benjamin, and which, as Sebald notes, corresponds to Benjamin's account of Baroque Trauerspiel (with which Hofmannsthal was familiar; see Sebald, 1978: 302; Benjamin, 1972: 29-33; Nicolaus, 2004: 132-55). Sebald also shares Benjamin's fascination with messianic images. He finds such an image in one of Joseph Roth's prose pieces, 'Beim Uhrmacher' ('At the Clock-maker's', 1931; Sebald misdates it to 1939, $U H$ : 113), where Roth recalls how a shop full of clocks made him as a child acutely aware of time, transience, and death. He imagined the clock-maker as having power over time and hence as able, by a small adjustment, to restore the world to its divinely appointed order. This messianic conception is taken further by Kafka in Das Schloss, as Sebald shows in a brilliant essay which forms the indispensable counterpart to his essay on the novel's landscape of death (UH: 97-103). Having discovered - independently of Evelyn Torton Beck (1971: 195) - that K.'s profession of land-surveyor is expressed in Hebrew by almost the same word as that for 'messiah' (cf. Robertson, 1985: 228-35), Sebald discloses an important strand of meaning in the novel: the exile K. has come to combat the Castle and its officials and to deliver the village from their tyranny, but his credentials, like those of all would-be messiahs, are dubious and he ultimately fails in his mission.

Whether or not one finds Sebald's outlook congenial, it carries the authority of a profound and coherent imaginative vision. It enables Sebald to respond to his favoured authors from an imaginative depth that matches their own. And it gives him, combined with his psychological empathy and acute sensitivity to words, an 
extraordinary critical stature, which one appreciates best when one moves on from reading single essays to seeing his critical ceuvre as a single coherent body. 


\section{References}

Améry, Jean (2002), Jenseits von Schuld und Sühne [1966], in Werke, ed. by Irene Heidelberger-Leonard, 9 vols. Stuttgart: Klett-Cotta, 2002-9, ii (2002), pp. 11-177.

Beck, Evelyn Torton (1971), Kafka and the Yiddish Theater. Madison, WI: Wisconsin UP.

Benjamin, Walter (1972), 'Review of Hugo von Hofmannsthal, Der Turm', in Gesammelte Schriften, ed. by Rolf Tiedemann and Hermann

Schweppenhäuser, 5 vols (1972-82), Frankfurt/Main: Suhrkamp, iii (1972), ed. by

Hella Tiedemann-Bartels, pp. 29-33.

Castle, Eduard (1943) (ed.), Das Geheimnis des großen Unbekannten: Die Quellenschriften mit Einleitung, Bildnis, Handschriftproben und ausführlichem Register. Vienna: Wiener Bibliophilen-Gesellschaft.

- - - (1952), Der große Unbekannte: Das Leben von Charles Sealsfield (Karl Postl). Vienna and Munich: Manutiuspresse.

Duebbert, Carole (1983), 'Hermann Brochs Verzauberung als "AntiHeimatroman"', in P.M. Lützeler (ed.), Brochs 'Verzauberung'. Frankfurt/Main: Suhrkamp, pp. 226-36.

Glaser, Horst Albert (1965), Die Restauration des Schönen: Stifters 'Nachsommer'. Stuttgart: Metzler.

Goldstücker, Eduard (1980), 'Kafkas Eckermann? Zu Gustav Janouchs Gespräche mit Kafka', in Claude David (ed.), Franz Kafka: Themen und Probleme. Göttingen: Vandenhoeck \& Ruprecht, pp. 238-55.

Heidelberger-Leonard, Irene (2005), 'Jean Amérys Werk - Urtext zu W.G. Sebalds Austerlitz?', in W.G. Sebald: Mémoire. Transferts. Images / Erinnerung. Übertragungen. Bilder, ed. by Ruth VogelKlein, Recherches Germaniques Special Edition 2, 117-28.

Hutchinson, Ben (2009), W.G. Sebald-Die dialektische Imagination. Berlin: de Gruyter.

Kafka, Franz (1990), Tagebücher, ed. Hans-Gerd Koch, Michael Müller and Malcolm Pasley (Frankfurt/Main: Fischer)

Long, Jonathan J. (2006), 'Austrian Prose Fiction, 1945-2000',in History of Austrian Literature 1918-2000, ed. by Katrin Kohl and Ritchie Robertson. Rochester, NY: Camden House, pp. 223-45.

Loquai, Franz (ed.) (1997), W.G. Sebald. Eggingen: Edition Klaus Isele.

Lunding, Erik (1946), Adalbert Stifter. Copenhagen: Nyt Nordisk Forlag.

Nestroy, Johann (2000), Stücke 24/II, ed. by John R.P. McKenzie. Vienna: Deuticke.

Nicolaus, Ute (2004), Souverän und Märtyrer: Hugo von Hofmannsthals späte Trauerspieldichtung vor dem Hintergrund seiner politischen und ästhetischen Reflexionen. Würzburg: Königshausen \& Neumann.

Rieckmann, Jens (1997), Hugo von Hofmannsthal und Stefan George: Signifikanz einer 'Episode' aus der Jahrhundertwende. Tübingen 
and Basel: Francke.

Robertson, Ritchie (1985), Kafka: Judaism, Politics and Literature. Oxford: Clarendon Press.

Schiffermüller, Isolde (2007), 'Grenzen der Lebensbeschreibung: Adalbert Stifters letzte autobiographische Schriften', in Stifter und Stifterforschung im 21. Jahrhundert: Biographie Wissenschaft-Poetik, ed. by Alfred Doppler et al. Tübingen: Niemeyer, pp. 23-36.

Schütte, Uwe (1997), Auf der Spur der Vergessenen: Gerhard Roth und seine Archive des Schweigens. Vienna: Böhlau.

- - - (2002), 'Der Hüter der Metaphysik. W.G. Sebalds Essays über die österreichische Literatur'. Manuskripte 155: 124-8.

- - - (2008), 'Ein Portrait des Germanisten als junger Mann. Zu W.G. Sebalds dissidenter Haltung gegenüber der Literaturwissenschaft in seinen akademischen Rezensionen'. Sprachkunst 34(2): 30932.

Sealsfield, Charles (1982), Das Kajütenbuch, ed. by Alexander Ritter. Stuttgart: Reclam.

Sheppard, Richard (2010), 'The Sternheim Years: W.G. Sebald's Apprenticeship and Theatrical Mission 1963-1970', in Saturn's Moons: A W.G. Sebald Handbook, ed. by Jo Catling and Richard Hibbitt. Oxford: Legenda, pp. ???-???

Thomas, Keith (1983), Man and the Natural World. London: Allen Lane. 